International Journal of Business Management and Economic Review

Vol. 4, No. 04; 2021

ISSN: 2581-4664

\title{
RELATIONSHIP CONTROL BETWEEN FIVE PRECEPTS PRACTICE AND ADULT HAPPINESS: THE EVIDENCE OF THE SURVEY IN VIETNAM
}

\author{
Nguyen Nghi Thanh \\ Ha Noi University of Home Affairs, Vietnam \\ Do Thu Huong \\ Ha Noi University of Home Affairs, Vietnam \\ Tran Quyet Thang \\ Ha Noi University of Home Affairs, Vietnam \\ Nguyen Thi Hop \\ Ha Noi National University, Vietnam \\ Phuong Huu Tung \\ Ha Noi University of Home Affairs, Vietnam \\ http://doi.org/10.35409/IJBMER.2021.3306
}

\begin{abstract}
Vietnam is a country of religious diversity, in which Buddhism has the most significant participation. In addition to practicing the Five Precepts, many Vietnamese people have registered for active mindfulness meditation classes recently. This fact has received significant attention from scientists to add to the evidence of previous studies and enrich the research literature. This study explores the role of mindfulness meditation practice as a moderator of the relationship between five precepts practice and subjective perception well-being of Vietnamese adults. This study was conducted through a cross-sectional survey using an intentional sampling technique $(n=200)$. Multivariable linear regression analysis and moderator regression were applied to prove the hypotheses. Research results show a positive and meaningful relationship between practicing mindfulness meditation, practicing the five precepts and feeling subjective happiness. In particular, mindfulness meditation acts as a moderating variable between the practice of the five sexes and the subjective feeling of happiness.
\end{abstract}

Keyword: Mindfulness, Five precepts, Happiness, Vietnamese adults.

\section{INTRODUCTION}

Buddhism was present in Vietnam about 2000 years ago, based on absorbing influences from both India and China. Vietnamese Buddhism converges both Northern and Southern Buddhist lines and is influenced by three major sects of Northern Buddhism, namely Zen Buddhism, Pure Land Buddhism and Tantric Buddhism. At the same time, Vietnamese Buddhism is also influenced by Confucianism, Taoism, and folk customs, so it creates distinct features. Vietnamese Buddhism has a history of nearly two decades (Vietnam Buddhist Sangha Executive Council, 2013). Vietnamese Buddhists got 14.9\% of the country's population (General Statistics Office of Vietnam, 2019).

Although with such a small number of Buddhists, mindfulness meditation is now very popular in Vietnam. Vietnamese people learn meditation thanks to the benefits that mindfulness 


\section{International Journal of Business Management and Economic Review}

Vol. 4, No. 04; 2021

ISSN: 2581-4664

meditation brings. Through mindfulness meditation courses, learners experience the process of self-reflection, self-introspection, and conscious action. Many Vietnamese find that practicing mindfulness meditation helps them form a philosophy of gracious living and gain wisdom of the mind. Many Vietnamese take mindfulness meditation courses because they see the benefits that meditation brings to them.

In recent years, there have been many studies on the benefits of mindfulness meditation for personal life. Mindfulness meditation enhances self-monitoring, self-awareness, reduces social anxiety, reduces depression, reduces neurosis, and promotes poor psychological well-being (Brown \& Ryan, 2003). in life (Kong, Wang \& Zhao, 2014), effects on spiritual health and well-being promotion (Birnie et al., 2010), self-compassion, goodness, negative feelings and enhancement positive emotions (Singh, 2018), subjective well-being (Akın Ümran \& Akın Ahmet, 2015), autonomous functioning in daily life, positive experiences in the present life (Brown \& Ryan, 2003), life satisfaction, emotional intelligence, openness to experience, attention, reduced impulsivity and increased receptivity to experience (Brown \& Ryan's, 2003).

For Vietnamese Buddhists, in addition to practicing meditation, practicing the five precepts (not killing, not stealing, not committing adultery, not lying, and not getting drunk and addicted) are reminded by pagodas and monks memorize and practice often.

There are very few studies on the relationship between mindfulness meditation practice and the five precepts. Several studies have found that the degree to which a Buddhist observes the five precepts and meditation is related to life satisfaction (Ariyabuddhiphongs, 2009), perceived happiness in life and healing (Hackney \& Sanders, 2003; Ariyabuddhiphongs \& Donnapat, 2010).

Happiness begins with not infringing upon themselves and infringing upon others. Perceived personal benefits mediate the relationship between adherence to the five precepts and subjective well-being (Ariyabuddhiphongs, Vanchai \& Jaiwong, Donnapat, 2010).

Religion is positively and significantly associated with subjective well-being. The relationship between religion and subjective well-being for religious activity is more potent than for measures of religion (Witter et al. 1985).

After holding their breath slowly, look at their emotions and think carefully. Then we should try to deal with them calmly and thoroughly. It will help the practitioner make more informed decisions in all aspects of life. Finally, it would help if they persevered in daily practice to entirely experience the state of happiness in their minds.

Buddhist values teach an understanding of real life, such as life suffering (Fuderich, 2007), compassion (Kraft, 1992), and inner peace (Lee et al., 2013). It has been suggested that Buddhist thinking following these particular doctrines implies a shift from moral to aesthetic (Voyce, 2015).

While there have been many studies on the relationship between religion and life satisfaction or happiness (Hackney \& Sanders, 2003), there seems to be no published research on the relationship between observance of the Five Precepts, personal wealth and happiness.

\section{LITERATURE REVIEWS}

\section{Mindfulness:}

There are different views on mindfulness. Malinowski (2013) argues that the concept of "mindfulness" has roots in Buddhist teachings and is a Buddhist practice, along with faith, effort, 


\section{International Journal of Business Management and Economic Review}

Vol. 4, No. 04; 2021

ISSN: 2581-4664

concentration, and wisdom. Meanwhile, Langer $(1989 ; 1992)$ suggested that mindfulness is a process of continuously drawing new and original distinctions between stimuli regardless of whether the current stimuli are perceived as trivial or essential. (Brown \& Ryan, 2003) defines mindfulness as responsive attention and awareness of events and experiences as they occur in the present moment.

The mindfulness trait is thought to predict autonomous functioning in daily life, and the state of mindfulness is linked to the temporary and experiential positive influence of present life. More simply, mindfulness is responsive attention and awareness of events and experiences as they occur in the present moment (Brown \& Ryan, 2003). Alternatively, any experience derived from internal or external stimuli is perceived, recognized, and accepted without evaluation (Furthermore, Kabat-Zinn, 2003; 2008). Mindfulness is all about awareness, and of course, that includes the practice of meditation.

Five Precepts:

The Five Precepts refer to the basic Buddhist training of restraining body and speech by abstaining from life, from taking what is not given, from lust, lying, and consuming alcohol, the god of indulgence (Mahatthanadull \& Mahatthanadull, 2018). The Five Precepts are the five prohibitions that Buddha invented to prevent evil thoughts, wrong speech, and unrighteous actions. The five commandments are: Do not kill; No theft or robbery; Do not commit adultery; Do not lie; Do not drink alcohol. These five things are practiced based on compassion and equality to eradicate individual sins and bring order and happiness to society. There are many studies on the five sexes. Khantipalo Bhikkhu (1994) argues that the five precepts are the moral code of Buddhism; by pledging to abide by the five prohibitions. Ariyabuddhiphongs (2009) states that observing the five precepts means committing to abstaining from killing, stealing, sexual misconduct, lying and idleness, and drinking and getting drunk; Meditation includes mindful attention to a breath or a walk (Ariyabuddhiphongs, 2009). The Five Precepts are the essence of all good qualities and the fulfillment of the higher stages of concentration and wisdom. It also promotes whatever sane state one already has (Soontaraporn Techapalokul, 2019).

\section{Happiness:}

There are two approaches to happiness, namely the hedonic approach, which focuses on happiness and therefore happiness is defined in terms of achieving pleasure and avoiding pain; and the eudaimonic approach, which focuses on meaning and self-perception and defines wellbeing in terms of the extent to which a person is fully functioning (Ryan \& Deci, 2001). Hedonism holds that happiness is the most tangible, being the joy we experience when performing rewarding activities, including seeking pleasure, perceiving emotional balance, maintaining satisfaction Satisfaction of life, the suppression of wants and needs, and happiness are short-term and intense (Delle Fave, Fausto, \& Marta, 2011). In other words, happiness is about achieving pleasure and avoiding pain and about the extent to which an individual is fully functioning (Ryan \& Deci, 2001). Altruism (eudaimonia) holds that happiness is the point of seeking personal growth, achievement of goals and goals, effort and motivation, and lasting happiness (Delle Fave, Fausto, \& Marta, 2011). According to Buddhism, happiness results from personal wealth: having wealth, using it, being free from debt, and engaging in a harmless profession (Ariyabuddhiphongs, Vanchai, \& Donnapat, 2010). 


\section{International Journal of Business Management and Economic Review}

Vol. 4, No. 04; 2021

ISSN: 2581-4664

\section{Relationship between mindfulness and happiness:}

Many studies have found a positive relationship between mindfulness and happiness. Soontaraporn Techapalokul (2019) suggests that mindfulness has a positive relationship between mindfulness and positive emotions and life satisfaction (Zelikson, 2016) and self-happiness (Klussman, Curtin, Langer, \& Nichols, 2020). Claire Crowley, Laura Ring Kapitula, \& Dana Munk, 2020; Akin, Umran, Akin, \& Ahmet, 2015).

Subjective happiness is positively predicted by mindfulness. Coping capacity is also based on mindfulness and subjective wellbeing (Akin, Umran, Akin, \& Ahmet, 2015). Mindfulness can act as a potential mediator in the relationship between emotion regulation and happiness (Satchit Prasun Mandal, Yogesh Kumar Arya, \& Rakesh Pandey, 2011). Mindfulness, which is associated with increased levels of happiness, is a mediator underlying this relationship; Meditation can lead to increased levels of mindfulness, which, in turn, can lead to increased levels of happiness (Sabrina Rose Teeter, 2016). Coping ability and subjective wellbeing are both positively predicted by mindfulness (Akın \& Akın, 2015).

Mindfulness is also a moderator in the relationship between life satisfaction and mental wellbeing (Edelweiss Bester, Pravani Naidoo, \& Anja Botha, 2016). Mindfulness and happiness appear to have a similar relationship (Hanley, Warner, \& Garland, 2015).

Relationship between the five precepts and happiness:

Acceptance of happiness mediates the relationship between the five precepts and happiness (Ariyabuddhiphongs \& Jaiwong, 2010). The Five Precepts benefit them to live a peaceful, harmonious life in society and a friendly manner (Ven. Nyanika, 2021; Kanda Pongpha \& Pharamaha Chitnaretes Wuthidhammo, 2016), establishing internal relationships. Healthier minds, more efficient actions, and more peace of mind (Rick Hanson, 2009). Buddhism is defined as the extent to which a Buddhist engages in observance, adherence to the five precepts, and meditation, which are related to life satisfaction (Ariyabuddhiphongs, 2009).

The authors have built a research model about what from the research overview, as shown in Figure 1 below.

Figure 1. The Research Model

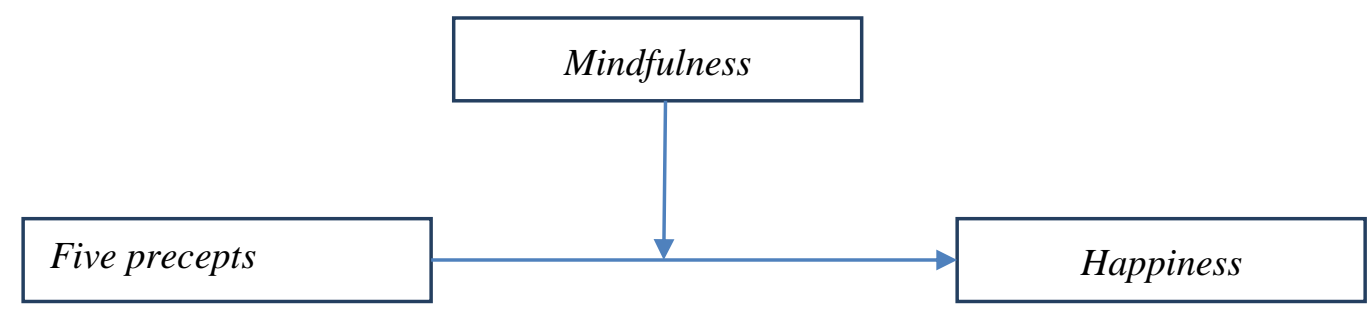

\section{Hypotheses}

Based on the above documents, the following hypotheses have been formed:

H1.Mindfulness has a positive and meaningful relationship with happiness.

$\mathrm{H} 2$. The five precepts have a positive and meaningful relationship to happiness.

H3. The Five Pre-Relationships Between Mindfulness and Happiness.

\section{RESEARCH METHOD}

Surveyed Area: 


\section{International Journal of Business Management and Economic Review}

Vol. 4, No. 04; 2021

ISSN: 2581-4664

The study was conducted at pagodas and temples in Hanoi in March 2020. It has more than 200 temples and shrines. Participating in the survey are elderly Hanoians who have attended meditation courses at pagodas and mindfulness meditation centers. At the beginning of the year, everyone's habit goes to temples and pagodas to pray for peace and luck for the family and practice the five precepts.

Research Samples and Methods:

To carry out this study, the authors conducted a survey, collecting opinions of the study participants in two steps: preliminary investigation and formal investigation.

Preliminary investigation:

The research team used a qualitative method by in-depth interviews with educational and psychologist researchers to adjust the research scale and improve the questionnaire to suit the characteristics of the survey area close. The questionnaire was built based on the results of the research overview and experts' opinions, including two parts. Part 1 collects demographic information of study participants such as age, gender, and occupation, and Part 2 collects information about study participants, including the mindfulness practice results, the practice of the five precepts and the level of happiness. Part 2 examines information about practicing the five precepts, the results of practicing mindfulness, and feeling happy. Based on Ariyabuddhiphongs \& Jaiwong's (2010) ideas, we build a measure of information gathering on five precepts by a questionnaire using the 5-point Linkert scale from 1. Strongly disagree with 5. Strongly agree on note: To get 10,000 USD, would they accept the following tasks? 1. Doing cattle slaughter for one year; 2 . Sell their employer's secrets to a company that competes with the company they are working for; 3 . Having sex with a stranger; 4 . If given the opportunity, will give false information to a bank or a financial company so that someone can borrow 100,000 USD; 5. Drink alcohol every day for a year. Collection of information on mindfulness practice using the State Mindfulness Scale (SMS): MSM was developed by (Analayo 2004; Bodhi, 1993; Bishop et al., 2004), based on previous research on mindfulness concepts and related structures (e.g., Langer, 1989). Researchers (Brown \& Ryan, 2003; Messick, 1995), Haynes, Richard, \& Kubany, 1995), and more recently Galia Tanay \& Amit Bernstein (2013), respectively, developed this measure. This measure includes two factors, State Mindfulness of Mind with 15 items and State Mindfulness of Body with six items. Because it did not match the study description, the State Mindfulness of Body factor was removed from the questionnaire. Collect information about feelings of happiness using The Depression-Happiness Scale (DHS) developed by McGreal \& Joseph (1993) with 25 items and then applied to research in many different areas of general health. of employed adults (Walsh, Joseph, \& Lewis, 1995). Items belonging to negative factors were removed from the questionnaire because they did not match the research objectives.

The English questionnaire was translated into Vietnamese by two professional interpreters, and the translation process is carried out according to the rules for cross-cultural adaptation. A single Vietnamese version was created after discussion and consensus between the translators and the principal investigator. A professional bilingual expert in education contributed to this version to create a final version. This final version was pre-tested on 60 participants selected to represent the population by age, sex, and education level. During the assessment, participants were asked to complete this final version. Subsequently, the most beautiful, minor edits were made to improve the sentence structure of the guide for better understanding, and the final 


\section{International Journal of Business Management and Economic Review}

Vol. 4, No. 04; 2021

ISSN: 2581-4664

Vietnamese version of the complete version was completed.

\section{Official investigation:}

A selection of students from universities in Hanoi participated in the study. They are the ones who have followed the mindfulness guidelines from instructors, monks, and experts on mindfulness practices. The questionnaire was sent directly to the respondents by the non-random sampling method. As a result, 200 good votes were obtained, achieving a response rate of 100\% demographic information of study participants (Table 1).

Table 1. Demographic characteristics of survey participants

\begin{tabular}{|c|c|c|c|c|c|c|c|c|c|}
\hline & \multicolumn{8}{|c|}{ Occupation } \\
\hline & & \multicolumn{2}{|c|}{ Manager } & \multicolumn{2}{|c|}{ Small bussiness } & \multicolumn{2}{|c|}{ Teacher } & \multicolumn{2}{|c|}{ Worker } \\
\hline & & $\begin{array}{l}\text { Coun } \\
\mathrm{t}\end{array}$ & $\begin{array}{l}\text { Row N } \\
\%\end{array}$ & $\begin{array}{l}\text { Coun } \\
\mathrm{t}\end{array}$ & $\begin{array}{l}\text { Row } \mathrm{N} \\
\%\end{array}$ & $\begin{array}{l}\text { Coun } \\
\mathrm{t}\end{array}$ & $\begin{array}{l}\text { Row N } \\
\%\end{array}$ & $\begin{array}{l}\text { Coun } \\
\mathrm{t}\end{array}$ & $\begin{array}{l}\text { Row N } \\
\%\end{array}$ \\
\hline \multirow{4}{*}{ Age } & 23-30 years & 22 & $34,9 \%$ & 12 & $19,0 \%$ & 16 & $25,4 \%$ & 13 & $20,6 \%$ \\
\hline & $31-40$ years & 13 & $31,0 \%$ & 7 & $16,7 \%$ & 13 & $31,0 \%$ & 9 & $21,4 \%$ \\
\hline & $41-50$ years & 8 & $17,0 \%$ & 11 & $23,4 \%$ & 12 & $25,5 \%$ & 16 & $34,0 \%$ \\
\hline & $\begin{array}{ll}\text { Above } & 50 \\
\text { years } & \end{array}$ & 12 & $25,0 \%$ & 12 & $25,0 \%$ & 9 & $18,8 \%$ & 15 & $31,2 \%$ \\
\hline \multirow{2}{*}{ Gender } & Female & 23 & $25,3 \%$ & 17 & $18,7 \%$ & 23 & $25,3 \%$ & 28 & $30,8 \%$ \\
\hline & Male & 32 & $29,4 \%$ & 25 & $22,9 \%$ & 27 & $24,8 \%$ & 25 & $22,9 \%$ \\
\hline \multirow{3}{*}{$\begin{array}{l}\text { Educatio } \\
\mathrm{n}\end{array}$} & Bachelor & 15 & $25,4 \%$ & 13 & $22,0 \%$ & 17 & $28,8 \%$ & 14 & $23,7 \%$ \\
\hline & College & 12 & $23,5 \%$ & 9 & $17,6 \%$ & 18 & $35,3 \%$ & 12 & $23,5 \%$ \\
\hline & Worker & 28 & $31,1 \%$ & 20 & $22,2 \%$ & 15 & $16,7 \%$ & 27 & $30,0 \%$ \\
\hline
\end{tabular}

\section{Research Results}

The $\mathrm{R}$ Programming language is used to analyze the reliability of the scale and the discovery factor. The analysis results suggest removing and merging some observed variables to help the scale evaluate concepts more accurately.

Analyzing the Reliability of the Scales:

They are testing the scales through Cronbach's Alpha reliability coefficient to identify and remove junk variables to avoid creating misleading factors when analyzing exploratory factor analysis. Cronbach's Alpha coefficient has a variable value in the interval $[0,1]$. If a measurement variable has a total correlation coefficient of Corrected Item - Total Correlation $\geq 0.3$, that variable meets the requirements (Cronbach, 1951; Taber, 2018). The verification criterion is that the Cronbach's Alpha coefficient must be greater than 0.6, and the correlation coefficient of the sum variable in each scale must be greater than 0.3 (Hair, Black, Babin, \& Anderson, 2010). Table 2 shows that the scales of the factors are all standard. Therefore, all the scales of the factors are reliable and used for subsequent factor analysis.

Table 2. Summary of Reliability and Relative Minimum Variables of Scales

\begin{tabular}{|l|l|l|l|}
\hline Scales & $\begin{array}{l}\text { Number of Reliability } \\
\text { variables } \\
\text { observed }\end{array}$ & $\begin{array}{l}\text { coefficients } \\
\text { (Cronbach Alpha) }\end{array}$ & $\begin{array}{l}\text { The correlation coefficient } \\
\text { of the smallest total } \\
\text { variable }\end{array}$ \\
\hline
\end{tabular}


International Journal of Business Management and Economic Review

Vol. 4, No. 04; 2021

ISSN: $2581-4664$

\begin{tabular}{|l|l|l|l|}
\hline \hline Mindfulness & 15 & 0.824 & 0.553 \\
\hline Five precepts & 5 & 0.818 & 0.547 \\
\hline Happiness & 16 & 0.842 & 0.651 \\
\hline
\end{tabular}

After testing Cronbach's Alpha, the author uses exploratory factor analysis (EFA) to preliminary evaluate the scales' unidirectional, convergent, and discriminant values . EFA was used by extracting the Principal Components Analysis Factor and Varimax rotation to group the factors. With a sample size of 200, the factor loading factors of the observed variables must be greater than 0.5; variables converge on the same factor and are distinguished from other factors. In addition, the Kaiser-Meyer-Olkin coefficient (KMO), which is an index used to consider the adequacy of factor analysis, must be within $0.5 \leq \mathrm{KMO} \leq 1$ (Cronbach, 1951; Taber, 2018; Hair et al. ., 2009). The analysis results in Table 3 show that all factor loading coefficients of the observed variables are greater than 0.5; Bartlett test with Sig meaning. $=0.000$ with $\mathrm{KMO}$ coefficient $=0.880$. All 35 items using EFA were extracted into three factors with Eigenvalues greater than one and Cumulative variance percent $=0.54(54 \%)$. Thus, the research model consisting of 2 independent variables and one dependent variable is used for linear regression analysis and subsequent hypothesis testing. 
International Journal of Business Management and Economic Review

Vol. 4, No. 04; 2021

ISSN: 2581-4664

Table 3. Exploratory factor analysis results

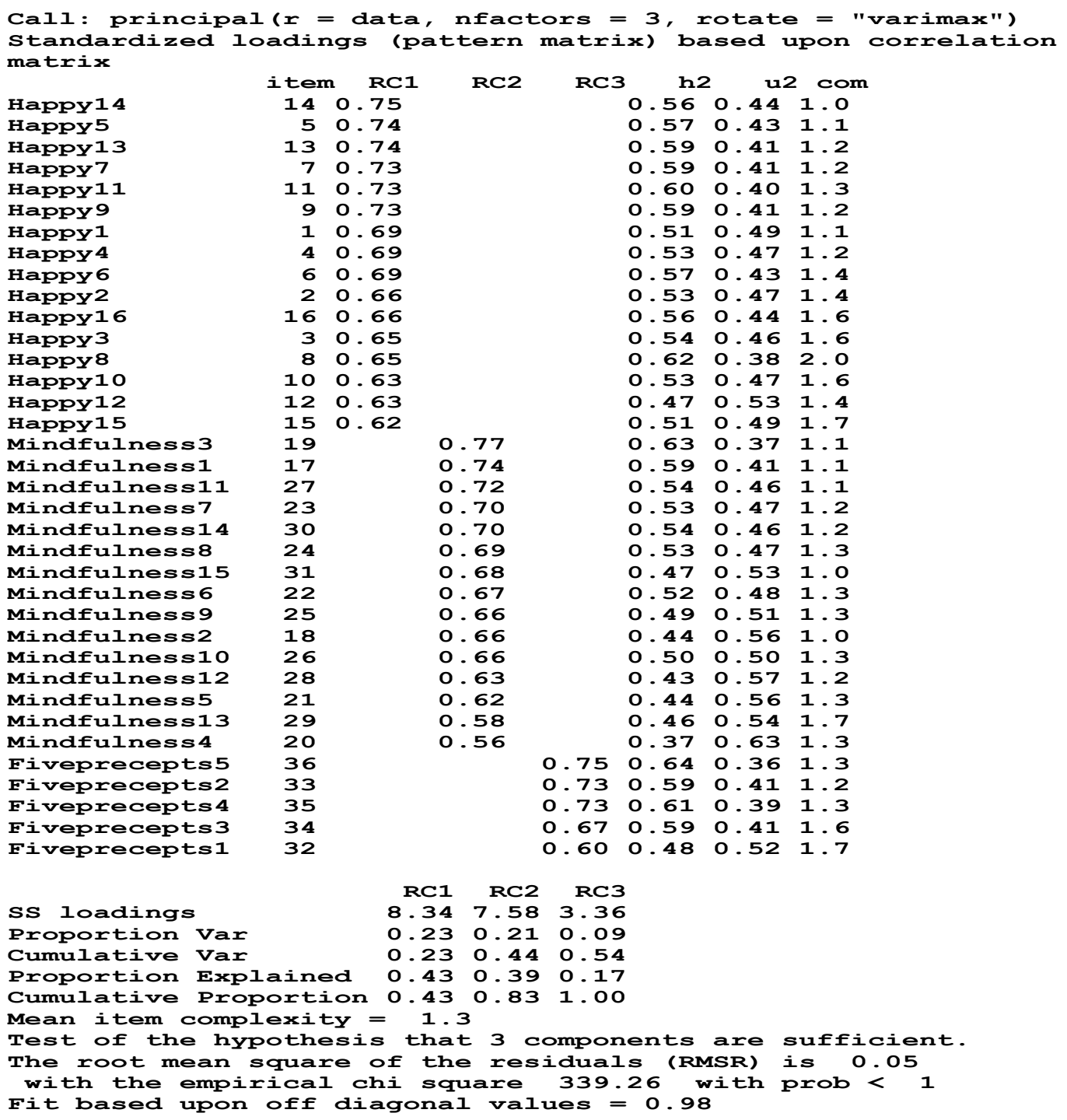

Pearson correlation analysis

The author uses Pearson correlation analysis to analyze the correlation between quantitative variables. Figure 2 shows that, at the 5\% level of significance, the correlation coefficient shows that the relationship between the dependent and independent variables is statistically significant (Sig. < 0.05). The magnitude of the correlation coefficients ensures that multicollinearity does not occur. Therefore, other statistics can be used to verify the relationship between variables. 
International Journal of Business Management and Economic Review

Vol. 4, No. 04; 2021

ISSN: 2581-4664

Figure 2. Pearson correlation analysis results

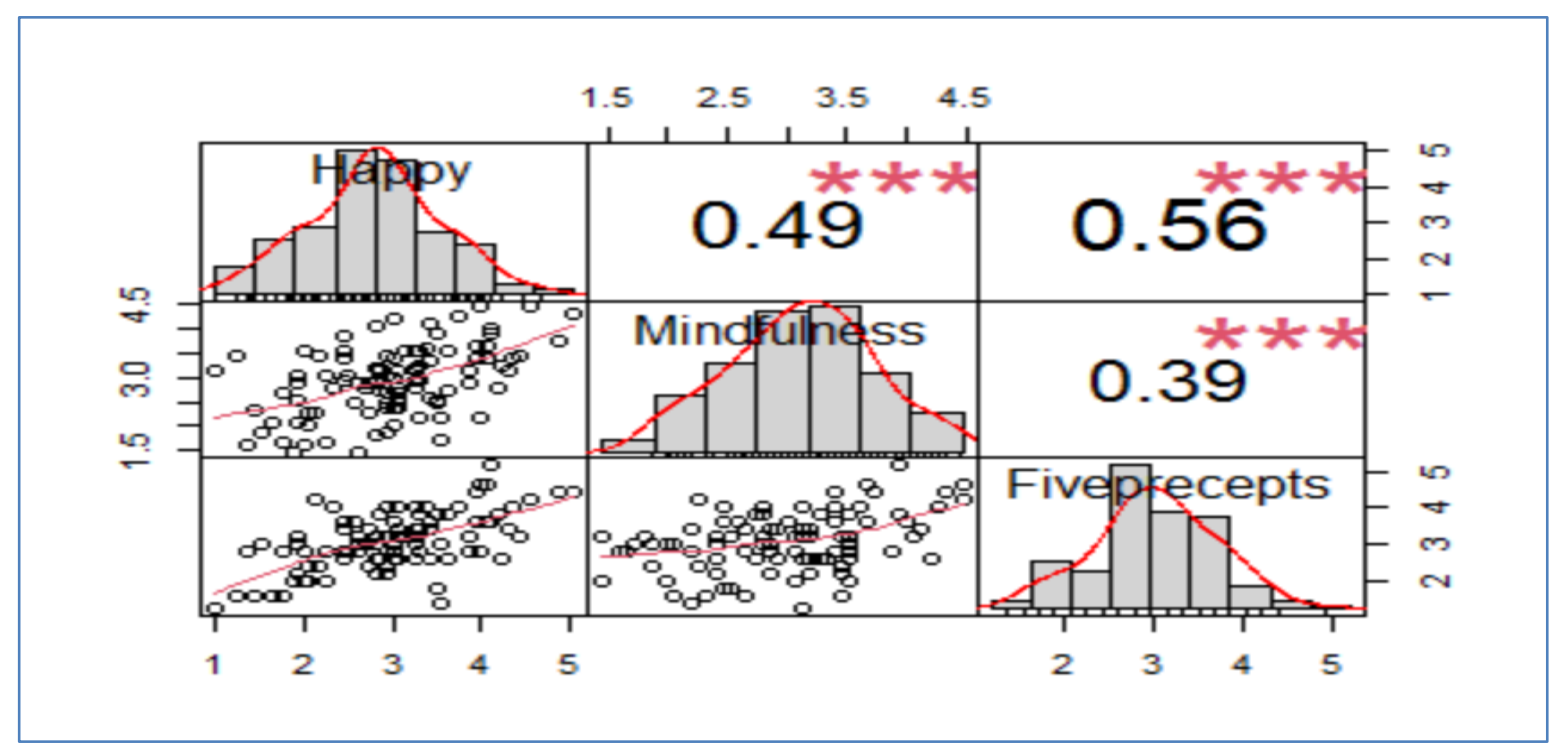

Moderation regression analysis:

Next, the research team analyzed Moderation regression Analysis to determine the Mindfulness variable that moderates the relationship between FivePrecepts and Happy variables. Table 4 shows that model 1 has $\mathrm{R} 2=0.362$, showing that the built linear regression model fits the dataset $=0.241 \%$. The model shows that the two independent variables have no statistical significance on the dependent variable, and especially the Mindfulness variable moderates the relationship between FivePrecepts and Happy variables.

Table 4. Moderation regression analysis 
International Journal of Business Management and Economic Review

Vol. 4, No. 04; 2021

ISSN: 2581-4664

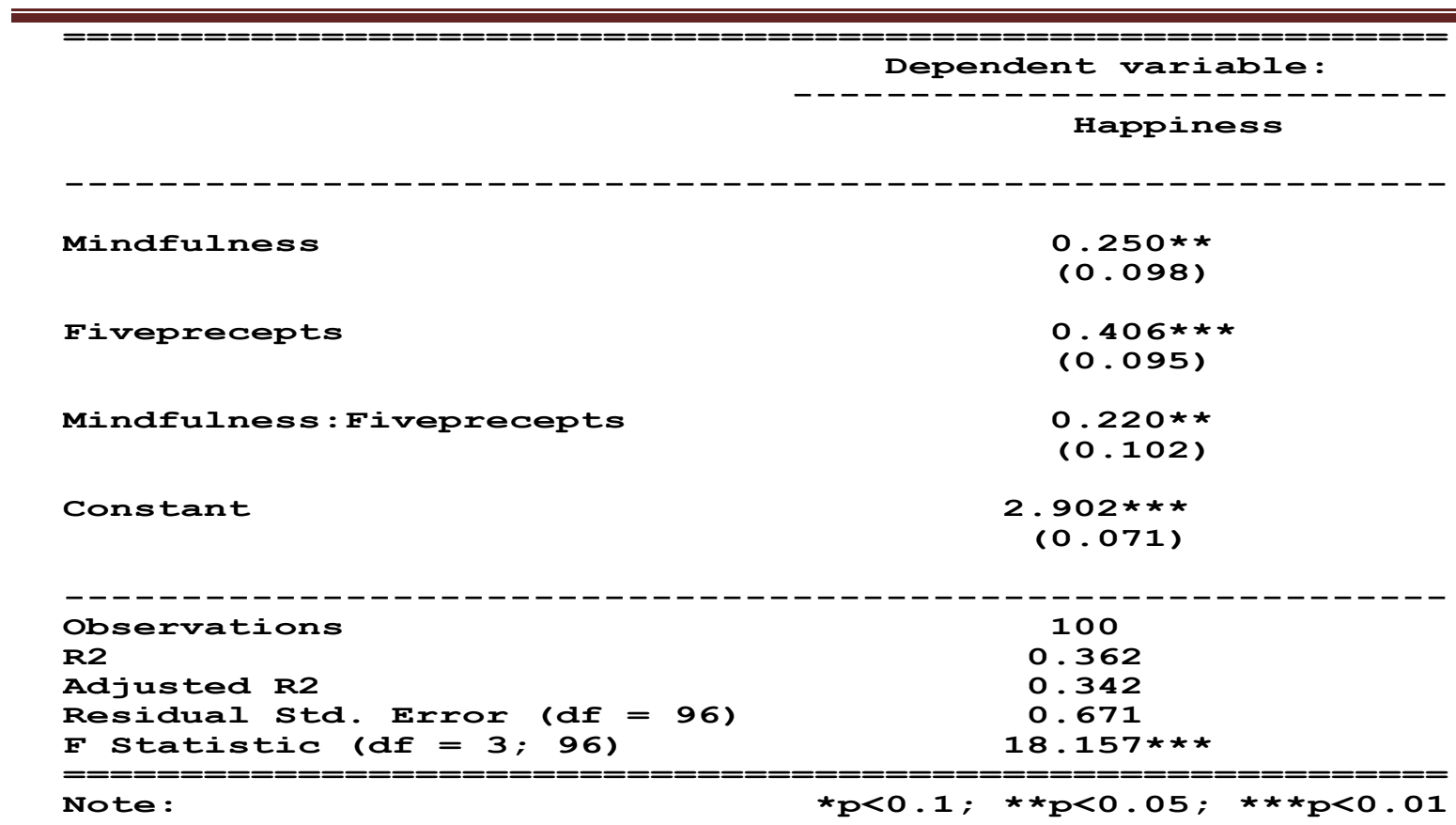

Table 4 shows that, with $95 \%$ confidence, the hypotheses proposed by the research team are accepted. Specifically, the FivePrecepts variable has the most substantial effect on the Happiness variable with $\beta=0.406$, and the second is the Mindfulness variable with $\beta=0.250$. The Mindfulness variable moderates the relationship between the FivePrecepts variable and the Happiness variable with $\beta=0.220$, which means that the increase or decrease of the Mindfulness variable makes the relationship between the FivePrecepts variable and the Happiness variable also increase or decrease respectively.

Discussion and Conclusion

Research results show that practicing mindfulness has a positive and meaningful impact on happiness. This result is similar to the finding of Soontaraporn Techapalokul (2019); Zelikson (2016), Klussman, Curtin, Langer, \& Nichols (2020), Claire Crowley, Laura Ring Kapitula, \& Dana Munk (2020), Akin, Umran, Akin, \& Ahmet (2015). Research results also show that practicing the five precepts has a positive and meaningful impact on happiness. This result is similar to the finding of Rick Hanson (2009); Along. Nyanika (2021); Kanda Pongpha \& Pharamaha Chitnaretes Wuthidhammo (2016); Ariyabuddhiphongs (2009) argues that the five precepts are beneficial for them to live a peaceful, harmonious life in society and with a friendly manner, related to life satisfaction.

Research results also show that mindfulness practice mediates the practice of the five precepts and feelings of happiness. This finding is similar to Sabrina Rose Teeter (2016), who suggested that mindfulness is associated with increased happiness levels, which is a mediator underlying this relationship; Meditation can lead to increased levels of mindfulness which, in turn, can lead to increased levels of happiness.

From the above results, it can be concluded that religious ritual practice has a significant relationship with subjective happiness. The degree of participation in religious practice is related to life satisfaction and life direction as it creates a sense of meaning and stimulates hope and optimism (Worthington, Kurusu, and McCullough) (1996). Buddhists practise the five precepts 
International Journal of Business Management and Economic Review

Vol. 4, No. 04; 2021

ISSN: 2581-4664

to receive "warm light," happiness and make spiritual life more meaningful.

\section{LIMITATIONS}

As with other empirical studies, there are limitations to this study that should be considered when discussing the results. First, our survey method reflects the respondents' subjective perception of the questions being investigated. Subjective data has some inherent disadvantages that are hard to avoid in surveys (Pakpour, Gellert, Asefzadeh, Updegraff, Molloy \& Sniehotta, 2016). Our data is collected over a single period of productional data that does not allow a dynamic assessment of changes in students' intentions and related behaviours regarding their college admissions, affecting their applicability (Xin, Liang, Zhanyou, \& Hua, 2019). Future research should combine cross-sectional and longitudinal studies.

The intentional sampling method has certain limitations, not fully reflecting population characteristics (Lin et al., 2016; Strong et al., 2018). Our survey was conducted within a cultural context of Vietnam and therefore requires more general statements that can be made by applying the development research model and research conclusions to other countries and cultures (Sun et al., 2012).

\section{ACKNOWLEDGMENTS}

Hanoi University of Home Affairs funded this research. The author sincerely thanks the student community of Hanoi University of Home Affairs for supporting the survey.

\section{Conflict of interest}

The author declares that there is no conflict of interest.

\section{REFERENCES}

Akin, Umran \& AKIN, Ahmet. (2015). Mindfulness and subjective happiness: The mediating role of coping competence. Ceskoslovenská psychologie, 59, 359-368.

Akın, Ümran; Akın, Ahmet. (2015).Mindfulness and subjective happiness: the mediating role of coping competence. Sakarya Üniversitesi Esentepe Yerleşkesi. https://hdl.handle.net/20.500.12619/44309.

Analayo. (2004). Satipatthana: The direct path to realization. Cambridge, England: Windhorse.

Ariyabuddhiphongs, V., \& Jaiwong, D. (2010). Observance of Buddhist Five Precepts, wealth, and happiness among Buddhists in Bangkok, Thailand. Archive for the Psychology of Religion, 32, 327-344.

Ariyabuddhphongs, V. (2009). Buddhist belief in merit (Punña), Buddhist religiousness and life satisfaction among Thai Buddhists in Bangkok, Thailand. Archive for the Psychology of Religion, 31(2), 191-213.

BIRNIE, K., SPECA, M. \& CARLSON, L.E. 2010. Exploring self-compassion and empathy in the context of Mindfulness-Based Stress Reduction (MBSR). Stress and Health, 26(5),359371

Bishop, S. R., Lau, M., Shapiro, S., Carlson, L, Anderson, N. D.. Car $\neg$ mody, J., . . . Devins, G. (2004). Mindfulness: A proposed operational definition. Clinical Psychology: Science and Practice, 11, 230-241. doi:10.1093/clipsy.bph077

Bodhi, B. (1993). A comprehensive manual of abhidhamma: The abhid-hammattha sangaha of 
International Journal of Business Management and Economic Review

Vol. 4, No. 04; 2021

ISSN: 2581-4664

acariya anuruddha. Seattle, WA: Pariyatti.

Brown, K. W., \& Ryan, R. M. (2003). The benefits of being present: Mindfulness and its role in method psychological well-being. Journal of Personality and Social Psychology, 84(4), 822848. https://doi.org/10.1037/0022-3514.84.4.822

Claire Crowley, Laura Ring Kapitula \& Dana Munk. (2020). Mindfulness, happiness, and anxiety in a sample of college students before and after taking a meditation course. Journal of American College Health. DOI: 10.1080/07448481.2020.1754839

Cronbach, L.J. Coefficient alpha and the internal structure of tests. Psychometrika,16, 297-334. https://doi.org/10.1007/BF02310555

Delle Fave, Antonella \& Massimini, Fausto \& Bassi, Marta. (2011). Hedonism and Eudaimonism in Positive Psychology, 2. 10.1007/978-90-481-9876-4_1.

Edelweiss Bester, Pravani Naidoom, Anja Botha. (2016).The role of mindfulness in the relationship between life satisfaction and spiritual wellbeing amongst the elderly. Social work (Stellenbosch. Online), 52(2). http://dx.doi.org/10.15270/52-2-503

Fuderich, Urakorn Khajornwit. (2007). Beyond Survival: A Study of Factors Influencing Psychological Resilience among Cambodian Child Survivors. Doctoral dissertation.University of Massachusetts Amherst, Amherst, MA, USA.

Galia Tanay \&Amit Bernstein. (2013). State Mindfulness Scale (SMS): Development and Initial Validation. Psychological Assessment, 25 (4), 1286 -1299. DOI: 10.1037/a0034044

General Statistics Office of Viet Nam. (2019). Completed results of the 2019 Viet Nam population and housing census. Statistical Publishing House

Hackney, C.H. and Sanders, G.S. (2003). Religiosity and Mental Health: A Meta-Analysis of Recent Studies. Journal for the Scientific Study of Religion, 42, 43-55. https://doi.org/10.1111/1468-5906.t01-1-00160

Hair, J. \& Black, W. \& Babin, Barry \& Anderson, Rolph. (2009). Multivariate data analysis. Prentice Hall. London.

Hanley, A., Warner, A. \& Garland, E.L.(2015). Associations Between Mindfulness, Psychological Well-Being, and Subjective Well-Being with Respect to Contemplative Practice. J Happiness Stud 16, 1423-1436. https://doi.org/10.1007/s10902-014-9569-5.

Haynes, S. N., Richard, D. C. S., \& Kubany, E. S. (1995). Content validity in psychological assessment:A functional approach to concepts and Psychological Assessment, 7, 238-247. doi: 10.1037/10403590.7.3.238.

Kabat-Zinn, J. (2003). Mindfulness-based interventions in context: Past, present, and future. Clinical Psychology: Science and Practice, 10(2),144-156.

Kabat-Zinn, J. (2008). Arriving at your own door. London: Piatkus Books

Kanda Pongpha \& Pharamaha Chitnaretes Wuthidhammo. (2016). Pañcasikkhāpada: Moral Practice for Family in Buddhism. Journal of International Buddhist Studies, 7(1), 47-52.

Kanda Pongpha \& Pharamaha Chitnaretes Wuthidhammo. (2016). Pañcasikkhāpada: Moral Practice for Family in Buddhism. Journal of International Buddhist Studies, 7(1), 47-52.

Khantipalo Bhikkhu, V. (1994). Buddhism explained. Chiangmai, Thailand: Silkworm Books.

Klussman K., Curtin N., Langer J., and Nichols A.L. (2020). Examining the effect of mindfulness on well-being: self-connection as a mediator. Journal of Pacific Rim Psychology, 14(e5). https://doi.org/10.1017/prp.2019.29.

Kong, F., Wang, X. \& zhao, j. (2014). Dispositional mindfulness and life satisfaction: the role 
International Journal of Business Management and Economic Review

Vol. 4, No. 04; 2021

ISSN: 2581-4664

of core self-evaluations. Personality and Individual Differences, 56,165-169

Kraft, Kenneth Lewis. (1992). Inner Peace, World Peace: Essays on Buddhism and Nonviolence. SUNY Series in Buddhist Studies; Albany: State University of New York Press.

Langer, E. J. (1989). Mindfulness. Reading. MA: Addison Wesley.

Langer, E.J. 1992. Matters of mind: mindfulness/mindlessness in perspective. Consciousness and Cognition, 1, 289-305

Lee, Yi-Chen, Yi-Cheng Lin, Chin-Lan Huang, and Barbara L. Fredrickson. 2013. The Construct and Measurement of Peace of Mind. Journal of Happiness Studies, 14, 571-90

Lin CY, Updegraff JA, Pakpour AH. (2016). The relationship between the theory of planned behavior and medi- cation adherence in patients with epilepsy. Epilepsy \& Behavior, 61, 231-236.

Mahatthanadull, Sanu \& Mahatthanadull, Sarita. (2018). The Five Precepts: Criteria and the Promotion of Individual and Social Peace. The Journal of the International Association of Buddhist Universities (JIABU), 11(3), 180-193.

MALINOWSKI, P. (2013). Flourishing through meditation and mindfulness. In: DAVID, S.A., BONIWELL, I. \& AYERS, C.A. (eds) The Oxford handbook of happiness. London: Oxford University Press.

Mcgreal, R., \&Joseph, S. (1993) The Depression-Happiness Scale. Psychological Reporb, $73,1279-1282$.

Meier, S. \& Stutzer, A. (2008), Is Volunteering Rewarding in Itself?. Economica, 75, 39-59. doi:10.1111/j.1468-0335.2007.00597.x.

Messick, S. (1995). Validity of psychological assessment: Validation of inferences from persons' responses and performances as scientific inquiry into score meaning. American Psychologist, $50,741-749$.

Pakpour AH, Gellert P, Asefzadeh S, Updegraff JA, Molloy GJ, Sniehotta FF. (2014). Intention and planning predicting medication adherence following coronary artery bypass graft surgery. Journal of Psychoso- matic Research, 77(4):287-95. https://doi.org/10.1016/j.jpsychores.2014.07.001 PMID: 25280826

Rick Hanson. (2009). Buddha's Brain: The Practical Neuroscience of Happiness, Love and Wisdom. New Harbinger Publications.

Ryan, R. M., \& Deci, E. L. (2001). On happiness and human potentials: A review of research on hedonic and eudaimonic well-being. Annual Review of Psychology, 52, 141-166. doi: 10.1146/annurev.psych.52.1.141.

Sabrina Rose Teeter. (2016). The effect of meditation on mindfulness and happiness. The Thesis of Master of Arts in Psychology. Western Carolina University.

Satchit Prasun Mandal, Yogesh Kumar Arya, \& Rakesh Pandey. (2011). Mindfulness, Emotion regulation and Subjective well-being: An Overview of Pathways to Positive Mental Health. Indian Journal of Social Science Researches, 8(1-2), 159-167.

Singh, A. K. (2018). Mindfulness and happiness among students: Mediating role of perceived stress . Journal of the Indian Academy of Applied Psychology, 44(2), 198-207.

Soontaraporn Techapalokul. (2019).Promoting the Buddhist Five Precepts of People of Mahar Aung Myay Township, Mandalay, Myanmar. JIABU, 12(1), 107-117.

Strong C, Lin CY, Jalilolghadr S, Updegraff JA, Brostro" m A, Pakpour AH. (2018). Sleep 
International Journal of Business Management and Economic Review

Vol. 4, No. 04; 2021

ISSN: 2581-4664

hygiene behaviours in Iranian adolescents: an application of the Theory of Planned Behavior. Journal of Sleep Research, 27(1), 23-31. https://doi.org/10.1111/jsr.12566 PMID: 28593637.

Sun Y, Fang Y, Lim KH, Straub D. (2012). User satisfaction with information technology services: A social capi- tal perspective. Information Systems Research, 23(4), 1195-211.

Taber, K.S. (2018). The Use of Cronbach's Alpha When Developing and Reporting Research Instruments in Science Education. Res Sci Educ 48, 1273-1296. https://doi.org/10.1007/s11165-016-9602-2.

Ü. Akın, A. Akın. (2015).Mindfulness and subjective happiness: the mediating role of coping competence. Ceskoslovenska Psychologie, 59(4), 359-368.

Ven. Nyanika. (2021). The Buddhist Approach to Establish Peace through Five Precepts. International Journal of Science and Research (IJSR), 9(11), 1165-1169.DOI: 10.21275/ART20204157.

Vietnam Buddhist Sangha Executive Council. (2013). Result report ensure and promote the rights of religious freedom in Vietnam through the actual actions of Vietnam Buddhist Sangha (Contribution to the general documents of Office of the UN High Commissioner for Human Rights, for process of universal periodic review - UPR).

Voyce, Malcolm. (2015). From Ethics to Aesthetics: A Reconsideration of Buddhist Monastic Rules in the Light of Michel Foucault's Work on Ethics. Contemporary Buddhism, 16, 299329.

Walsh, J., Joseph, S., \& Lewis, C. A. (1995). Internal reliability and convergent validity of the Depression-Happiness Scale with the General Health Questionnaire in an employed adult sample. Psychological Reports, 76(1), 137-138. https://doi.org/10.2466/pr0.1995.76.1.137/

Worthington, E. L., Kurusu, T. A., McCullough, M. E., Sandage, S. J. (1996). Empirical research of religion and psychotherapeutic processes and outcomes. Psychological Bulletin, $119,448-487$.

Xin Z, Liang M, Zhanyou W, Hua X (2019) Psychosocial factors influencing shared bicycle travel choices among Chinese: An application of theory planned behavior. PLOS ONE 14(1): e0210964. https://doi.org/10.1371/journal.pone.0210964.

Zelikson D.I.(2016). The interrelation between mindfulness and subjective well-being [Elektronnyi resurs]. Sovremennaia zarubezhnaia psikhologiia $=$ Journal of Modern Foreign Psychology, 5(3), 92-99. doi:10.17759/jmfp.2016050310. 